\title{
Spent sulphite liquor utilization by xylose-assimilating yeast pachysolen tannophilus, capable of bioethanol producing
}

\author{
Olga Bolotnikova ${ }^{1,2,}{ }^{*}$, Julia Bazarnova ${ }^{2}$, Ekaterina Aronova ${ }^{2}$, Natalia Mikhailova $^{3}$, Tatiana Bolotnikova $^{2}$ and Jing Pu ${ }^{4}$ \\ ${ }^{1}$ Petrozavodsk State University, Lenina Str. 33, Petrozavodsk, 185910, Republic of Karelia, Russia \\ ${ }^{2}$ Peter the Great St. Petersburg Polytechnic University, Polytechnicheskaya Str. 29, Saint Petersburg, 195251, Russian Federation \\ ${ }^{3}$ Saint-Petersburg State Institute of Technology, Moskovskiy Av. 26, Saint Petersburg, 190013, Russian Federation \\ ${ }^{4}$ Shanghai Jlao Tong University, Department of Food Science, School of Agriculture \& Biology, \\ 800 Dongchuan Rd., Shanghai, 200240, China
}

\begin{abstract}
The xylose-assimilating capacity of yeast Pachysolen tannophilus to utilize sugars in spent sulphite liquor samples (pulp mill waste) with a different concentration of hexoses and pentoses was studied. The consumption of hexoses (D-glucose, D-mannose, D-galactose) and pentose (D-xylose) in such substrates reached $90.0-97.5 \%$ and $49.12-67.45 \%$, respectively. The ethanol production from sugars in spent sulphite liquor by different strains of the yeast P. tannophilus was demonstrated. The maximum specific rate and ethanol yield reached 9.32-11.45 g 1-1 and 0.28-0.37 g g sugars-1, respectively. Thus, the principle possibility of using xylose-assimilating P. tannophilus yeast to obtain bioethanol from sulfite liquor with a different ratio of hexoses and pentoses was proved. According to theoretical calculations, this method will provide up to 42.6 liters of ethanol from $100 \mathrm{~kg}$ of sulfite liquor containing $55.6 \% \mathrm{D}$-xylose, 24.7\% D-glucose, $8.7 \%$ D-mannose, 7.6\% D-galactose, 3.7\% L-arabinose. A future-oriented perspective on bioethanol production from pulp and paper industry wastes by the yeast $\mathrm{P}$. tannophilus is considered.
\end{abstract}

\footnotetext{
Corresponding author: olga-bolotnikova@rambler.ru
} 


\section{Introduction}

Nowadays the state Policy of the Russian Federation strictly regulates industrial wastewater discharge, that can have a negative ecological impact on surface water and groundwater [1]. Spent sulphite liquor (pulp mill waste) usually contains mixes of different sugars $[2,3]$. Their presence creates the favorable conditions for growth of different pathogenic microorganisms, that reduces water quality in cities and limits its domestic use [4]. Therefore, efficient method development strategy for sugar utilization from wastewater have become the most important objective to reduce anthropogenic pressures on freshwater ecosystems.

It is known that spent sulphite liquor, a by-product in the manufacture of wood pulp by the sulfite process, contains significant amounts of hexoses and pentoses except toxic impurities $[3,5,6]$. The yeast Pachysolen tannophilus has been identified as being able to convert D-glucose, D-mannose, D-galactose and D-xylose to ethanol, so it is a unique biocatalyst for hexoses and pentoses utilization from pulp mill waste and wastewater $[7,8]$. Today, however, bioethanol is by far the most widely available; it is an important product in the fuel market as a motor fuel or a gasoline additive. It seems to be a viable contender to replace fossil fuels [9].

The purpose of the present study is therefore to analyze the efficient degree of hemicellulose-derived sugars utilization in spent sulfite liquor and evaluate the bioethanol production level by different strains of $\mathrm{P}$. tannophilus.

\section{Methods}

The strains of xylose-assimilating yeast P.tannophilus Y1532, Y-1533 and Y-1534 (Museum of Microorganisms, All-Russian Research Institute of Hydrolysis, St. Petersburg) were chosen for the experience. The yeasts were grown in $750 \mathrm{ml}$ round-bottom flasks containing $100 \mathrm{ml}$ of the medium with $2.0 \%$ D-xylose, $2.0 \%$ peptone and $0.5 \%$ yeast extract on a shaker $(100 \mathrm{rpm})$ at $+30 \pm 20 \mathrm{C}$ for $24 \mathrm{~h}$. After that P.tannophilus biomass for fermentations were reached in diluted spent sulphite liquor samples under control limited aeration in $1.8 \mathrm{~L}$ fermenter Biostat $\mathrm{M}$ at $+30 \pm 20 \mathrm{C}, \mathrm{pH}=5.0 \pm 0.5,600 \mathrm{rpm}$, 10-12 h [10]. The three samples of spent sulphite liquor (Svetogorsk Pulp and Paper Mill) with different amount of hexoses and pentoses (SSL No. 1-3) were provided by
All-Russian Research Institute of Hydrolysis, (St. Petersburg), Table 1. The inhibitors concentrations (\%): 0.002 (furfural), 0.01 (hydroxymethylfurfural), 0.8 (lignin derivatives) and $0.10 \mathrm{~g} 1-1$ acetic acid [11]. The samples of spent sulphite liquor were reached ammonium sulfate $(0.05 \%)$ and superphosphate $(0.03 \%)$ after that fermented under control limited aeration in fermenter Biostat $\mathrm{M}$ at $+30 \pm 20 \mathrm{C}, \mathrm{pH}=4.5 \pm 0.5,600 \mathrm{rpm}$, $36 \mathrm{~h}$. The inoculation yeast concentration was $15 \mathrm{~g} \mathrm{l}-1$ (dry $75 \%$ ). Inoculation was performed using cultures in the middle of the exponential growth phase. The concentration of reducing sugars was determined with the Foelling reagent.

Ethanol and different sugars were determined by gas chromatography using a Vista 600 device (Varian, USA) with a steel column $(2000 \times 3 \mathrm{~mm})$. Ethanol was determined under the following condition: stationary phase, Cromosorb-101, temperature of the column $1000 \mathrm{C}$, temperature of the evaporation $1200 \mathrm{C}$, carrier

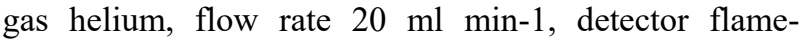
ionization type, internal standard isobutanol. Different hexoses and pentose was determined under the following conditions: stationary phase, Cromosorb-100, temperature of the column $2000 \mathrm{C}$, temperature of the evaporation $1200 \mathrm{C}$, carrier gas nitrogen, flow rate $30 \mathrm{ml}$ min-1, detector flame-ionization type, internal standard sorbitol. The error for each experimental value is no higher than $5.0 \%$.

\section{Results and Discussion}

It is known that the composition of monosaccharides in spent sulfite liquor depends on the type of plant material. Thus, softwood spent sulfite liquor contains predominantly hexoses (D-glucose, D-mannose, Dgalactose, and L-ramnose), whereas pentoses (D-xylose and L-arabinose) are the major sugars in hardwood spent sulfite liquor [2,3]. Therefore, we used samples of softwood spent sulfite liquor (SSL No. 1) as well as hardwood and softwood mixes (SSL No. 2-3) with different concentrations and percent composition of hexoses and pentoses (Table 1). The substrates were fermented with a batch culture of the yeast $P$. tannophilus Y-1532, which is the convenient investigating object for bioconversionof D-xylose $[11,12]$. The degrees of reducing sugar concentrations as well as the ethanol concentration and ethanol yield were calculated (Table 2). 
Table 1. The quantitative composition of sugars in different samples of spent sulphite liquor (SSL)

\begin{tabular}{|c|c|c|c|c|c|c|c|c|}
\hline \multirow{4}{*}{$\begin{array}{l}\text { Sample } \\
\text { number }\end{array}$} & \multicolumn{8}{|c|}{ SUGARS } \\
\hline & \multicolumn{5}{|c|}{ hexoses } & \multicolumn{3}{|c|}{ pentoses } \\
\hline & \multicolumn{4}{|c|}{ concentration, $\mathrm{g} \mathrm{l}^{-1}$} & \multirow{2}{*}{$\%$ of total } & \multicolumn{2}{|c|}{ concentration, $\mathrm{g} \mathrm{l}^{-1}$} & \multirow{2}{*}{$\%$ of total } \\
\hline & D-glucose & D-mannose & D-galactose & L-rhamnose & & D-xylose & L-arabinose & \\
\hline SSL No. 1 & $11.20 \pm 0.52$ & $20.80 \pm 1.02$ & 0.0 & $0.80 \pm 0.04$ & 72.25 & $9.00 \pm 0.32$ & $3.60 \pm 0.12$ & 27.75 \\
\hline SSL No. 2 & $3.75 \pm 0.13$ & $16.60 \pm 0.83$ & $3.33 \pm 0.07$ & $0.95 \pm 0.03$ & 59.00 & $12.93 \pm 0.60$ & $4.17 \pm 0.16$ & 41.00 \\
\hline SSL No. 3 & $2.80 \pm 0.07$ & $7.95 \pm 0.31$ & $2.45 \pm 0.12$ & $0.50 \pm 0.02$ & 41.80 & $17.85 \pm 0.84$ & $1.20 \pm 0.04$ & 58.20 \\
\hline
\end{tabular}

Table 2. Bioconversion of sugars in spent sulphite liquor by P. tannophilus Y-1532

\begin{tabular}{|c|c|c|c|c|c|}
\hline \multirow{3}{*}{$\begin{array}{l}\text { Sample } \\
\text { number }\end{array}$} & \multicolumn{3}{|c|}{ SUGARS } & \multicolumn{2}{|c|}{ ETHANOL } \\
\hline & \multirow{2}{*}{ Total, $\mathrm{g} \mathrm{l}^{-1}$} & \multicolumn{2}{|c|}{$\%$ of total } & \multirow{2}{*}{$\begin{array}{c}\text { Concentration, } \\
\mathrm{g} \mathrm{l}^{-1}\end{array}$} & \multirow{2}{*}{$\begin{array}{l}\text { Yield, } \\
\text { g g sugars }\end{array}$} \\
\hline & & hexoses & pentoses & & \\
\hline SSL No.1 & $45.40 \pm 1.73$ & 97.50 & 57.14 & $11.45 \pm 0.46$ & $0.37 \pm 0.01$ \\
\hline SSL No. 2 & $41.70 \pm 1.05$ & 93.4 & 49.12 & $9.32 \pm 0.41$ & $0.28 \pm 0.01$ \\
\hline SSL No. 3 & $32.75 \pm 1.08$ & 90.00 & 67.45 & $11.13 \pm 0.49$ & $0.33 \pm 0.01$ \\
\hline
\end{tabular}

The hexose utilization efficiency by yeast cells in each case was significantly higher $(90.0-97.5 \%)$. The maximal pentoses consumption $(67.45 \%)$ was shown for SSL No. 3 in which the amount of different hexoses was the lowest possible. The best ethanol concentration and ethanol yield were 11.13-11.45 $\mathrm{g} \mathrm{l}^{-1}$ and $0.33-0.37 \mathrm{~g} \mathrm{~g}^{-1}$ of consumed sugars, respectively, in SSL No. 1 where hexoses were predominant $(72.25 \%)$ and in SSL No. 3 where pentoses were predominant $(67.45 \%)$. So, there is a principal possibility to use xylose-assimilating yeast $\mathrm{P}$. tannophilus to obtain bioethanol from spent sulfite liquor with a various amount of hexoses and pentoses.

It is known that xylose-assimilating P. tannophilus strains are typically characterised by different levels of ethanol production from D-glucose and D-xylose, the main sugars of sulfite waste liquor $[13,14]$. Therefore, the efficiency of ethanol fermentation from sample SSL No. 3 was evaluated for various P. tannophilus strains (Table 3).

Table 3. Ethanol production from sugars of SSL No. 3 by the different strains of the yeast P. tannophilus

\begin{tabular}{|c|c|c|c|c|}
\hline \multirow{2}{*}{ Strain number } & \multicolumn{2}{|c|}{ Utilized, \% } & \multicolumn{2}{|c|}{ Ethanol } \\
\hline & D-glucose & D-xylose & Concentration, $\mathrm{g} \mathrm{l}^{-1}$ & $\begin{array}{l}\text { Volumetric rate, } \\
\qquad \mathrm{g} \mathrm{l}^{-1} \mathbf{h}^{-1}\end{array}$ \\
\hline Y-1532 & \multirow{3}{*}{97.0} & 72.00 & $11.13 \pm 0.49$ & $0.33 \pm 0.01$ \\
\hline Y-1534 & & 79.00 & $12.68 \pm 0.62$ & $0.53 \pm 0.02$ \\
\hline Y-1533 & & 76.00 & $14.07 \pm 0.53$ & $0.58 \pm 0.02$ \\
\hline
\end{tabular}

It is easily seen the difference between the degree of D-xylose consumption and the efficiency of bioethanol production by yeast cells. The maximum ethanol concentration and volumetric ethanol productivity were obtained with sugar utilization in SSL No. 3 by the culture of $\mathrm{P}$. tannophilus $\mathrm{Y}-1533$ and reached $14.07 \pm 0.70 \mathrm{~g} \mathrm{l}-1$ and $0.58 \pm 0.03 \mathrm{~g} \mathrm{l}-1 \mathrm{~h}-1$, respectively.
This strain can be used as a biocatalyst for producing ethanol from spent sulfite liquor. According to theoretical estimations, the application of such method allows to provide 42.6 liters of bioethanol from $100 \mathrm{~kg}$ of spent sulfite liquor, contained $55.6 \%$ of D-xylose, $24.7 \%$ of D-glucose, $8.7 \%$ of D-mannose, $7.6 \%$ of Dgalactose and $3.7 \%$ of L-arabinose. So, ethanol yield will 
be increased of $70 \%$ compared to traditional method of hexose fermentation $[15,16]$.

The sulfite process is currently in wide use in more than 25 the pulp and paper companies in the Northwestern Federal District [17-22]. However, an effective strategy for recovery of hemicelluloses by biochemical utilization has not yet been determined due to the presence of toxic impurities as well as high Dxylose level that cannot be fermented by the yeasts Saccharomyces sp. and Shizosaccharomyces sp.

The inclusion of xylose-assimilating yeast $P$. tannophilus as a new biocatalyst in standard hydrolysis and fermentation production process does not require any principal changes. However, the yeast strains are able to ferment D-xylose to ethanol using microaerobic conditions. So, technological formalization of this method will lead to modernization process of the pulp and paper industry companies in the Northwestern Federal District of Russian Federation.

\section{Conclusions}

The principal possibility of using xylose-assimilating yeast P. tannophilus for spent sulphite liquor utilization associated with the production of bioethanol has been established. The inclusion of this biocatalyst in the standard hydrolysis and fermentation production scheme will significantly reduce the financial costs for the pulp and paper mill wastewater treatment.

\section{References}

1. Gosudarstvennii doklad "O sostoyanii i ispolzovanii vodnih resursov Rossiiskoi Federacii v 2017 godu",

http://www.mnr.gov.ru/docs/gosudarstvennye_doklady/o _sostoyanii_i_ispolzovanii_vodnykh_resursov_rossiysko y_federatsii/ (2017)

2. L. Simão1, D. Hotza, F. Raupp-Pereira1, et. al., Ceramica, 64, 371 (2018)

3. J. Fernandez-Rodríguez, A. García, A. Coz, et. al., Chem. Engineer. Transact., 45 (2015)

4. Federalnii zakon ot 29 iyulya 2017 g. № 225F3 "O vnesenii izmenenii v Federalnii zakon «O vodosnabjenii i vodootvedenii» $\mathrm{i}$ otdelnie zakonodatelnie akti Rossiiskoi Federacii", https://www.garant.ru/products/ipo/prime/doc/71632832/

5. M. Alexandri, H. Papapostolou, A. Vlysidis, et. al., J. Chem. Tech. Biotech., 91, 11 (2016)

6. T. Llano, N. Quijorna, A. Andrés, and A. Coz, Biotech. Report., 15 (2017)

7. O.I. Bolotnikova, N.M. Mikhailova, and A.I. Ginak, Mycol. Phytopathol., 46, 2 (2012)

8. O.I. Bolotnikova, N.M. Mikhailova, and A.I. Ginak, Mycol. Phytopathol., 47, 5 (2013)

9. A. Bušic, N. Marđetko, S. Kundas, et. al., Food Technol. Biotechnol., 56, 3 (2018)

10. O.I. Bolotnikova, N.M. Mikhailova, A.I. Ginak, et. al., Proceed. Petrozavodsk state univers., 6 (2010)
11. O.I. Bolotnikova, N.P. Mikhailova, and A.I. Ginak, Izvestiya Sankt-Peterburgskogo gosudarstvennogo tehnologicheskogo instituta (tehnicheskogo universiteta), 20 (46) (2013)

12. O.I. Bolotnikova, N.P. Mikhailova, and A.I. Ginak, Izvestiya Sankt-Peterburgskogo gosudarstvennogo tehnologicheskogo instituta (tehnicheskogo universiteta), 18(44) (2013)

13. E.N. Yablochkova, O.I. Bolotnikova, N.P. Mikhailova, et. al., Appl.Biochem. Microb., 39, 3 (2003)

14. N.K. Harner, X. Wen, P.K. Bajwa, et. al., J. Ind. Microbiol Biotechnol., 42, 1 (2015)

15. N. Akhtara, A. Karnwala, A. Kumar Upadhyaya, et. al., As. J. Microb. Biotech. Environ. Scien. Paper, 20, 202-206 (2018)

16. S.H. Mohd Azhar, R. Abdulla, S.A. Jambo, et. al., Biochem Biophys Rep., 10 (2017)

17. Cellyulozno-bumajnie kombinati i proizvoditeli cellyulozi i bumagi, https://www.wikiprom.ru/20/cellyulozno-bumajnye-kombinaty.html

18. Russkova, I., Dolgikh, N., Salkutsan, V. et. al., Russia's arctic is as an object of environmental monitoring. IOP Conference Series: Earth and Environmental Science, 302 (2019)

19. Idrisova, J. I., Myasnikov, V. N., Uljanov, A. I., et. al., Increasing the efficiency of labor protection in the enterprise. The International Conference on Information Networking, 586-588 (2018)

20. Rumyantseva, N. V., Doronin, A. S., and Primak, E. A. Improvement of the system of selective collection of household waste in latvia. The International Conference «Management of Municipal Waste as an Important Factor of Sustainable Urban Development» (WASTE), 60-62 (2018)

21. Zybina, O.A., Zorde, E.S., and Savelyev, D.I. Fire Safety of Municipal Solid Waste Land Fills. The International Conference «Management of Municipal Waste as an Important Factor of Sustainable Urban Development» (WASTE), 89-91 (2018)

22. Bazarnova Y., Bolotnikova O., Michailova N., and $\mathrm{Pu}$ J. Optimization of parameters of alcohol fermentation of xylose-containing inedible substrates using the yeast Pachysolen Tannophilus. MATEC Web International Scientific Conference on Energy, Environmental and Construction Engineering. 245, 5 (2018)

\section{Acknowledgment}

This work was supported by the grant No 18-44-100001 from Russian Foundation for Basic Research (RFBR). 